\title{
Remediasi Merkuri (Hg) pada Air Limbah Tambang Emas Rakyat dengan Metode Lahan Basah Buatan Terpadu
}

\section{Remediation of Mercury $(\mathrm{Hg})$ in Tailing of Artisanal Gold Mines using Integrated Constructed Wetland Method}

\author{
HANIES AMBARSARI ${ }^{1}$ DAN AULIA QISTHI ${ }^{2}$ \\ 1*Balai Teknologi Pengolahan Air dan Limbah (BTPAL) - Badan Pengkajian dan Penerapan Teknologi (BPPT) Gedung 820 \\ Geostech, Kawasan Puspiptek Serpong, Tangerang Selatan, Banten 15314 \\ ${ }^{2}$ Program Studi Teknik Lingkungan, Fakultas Teknik, Universitas Indonesia \\ hanies.ambarsari@bppt.go.id
}

\begin{abstract}
An integrated constructed wetland method was applied in this environmental remediation study to reduce the levels of mercury $(\mathrm{Hg})$ in gold mine tailing with Phragmites australis and microbes in the compost. Wastewater which was used in this study consisted of original gold mine tailing wastewater that was contaminated by mercury up to $27 \mathrm{ppb}$ and artificial wastewater consisting of various doses of mercury in $30 \mathrm{ppb}, 60 \mathrm{ppb}$ and $90 \mathrm{ppb}$ levels. The results showed that the efficiency levels of mercury after treatment reached $99.6 \%$ in both the original wastewater as well as 30 ppb wastewater of mercury, while the efficiency levels for wastewater of $60 \mathrm{ppb}$ and $90 \mathrm{ppb}$ levels of mercury reached $99.8 \%$. This study also showed that the highest accumulation of mercury was found in the roots, with the total accumulation of mercury in Phragmites australis was $3.502 \mathrm{mg} / \mathrm{kg}, 5.102 \mathrm{mg} / \mathrm{kg}$ and $12.066 \mathrm{mg} / \mathrm{kg}$ in artificial wastewater at $30 \mathrm{ppb}, 60 \mathrm{ppb}$ and $90 \mathrm{ppb}$ levels, respectively. The highest accumulation of mercury in the roots, compared with those at different parts of the plant, can be used as the proof that the microbes from the compost present at the roots are involved in the mercury accumulation process by the plant.
\end{abstract}

Keywords: constructed wetland, mercury $(\mathrm{Hg})$, artisanal gold mine, tailing

\section{ABSTRAK}

Suatu metode lahan basah buatan terpadu diterapkan pada penelitian remediasi lingkungan dengan menggunakan tanaman Phragmites australis dan mikroba pada kompos untuk mengurangi konsentrasi merkuri $(\mathrm{Hg})$ pada air limbah. Air limbah yang digunakan pada penelitian terdiri dari limbah asli tambang emas rakyat Pongkor dengan konsentrasi 27 ppb dan limbah buatan dengan konsentrasi 30 ppb, 60 ppb dan $90 \mathrm{ppb}$. Hasil penelitian menunjukkan tingkat efisiensi penurunan konsentrasi $\mathrm{Hg}$ yang dihasilkan adalah sebesar 99,8\% pada air limbah buatan dengan konsentrasi 60 ppb dan 90 ppb, serta sebesar 99,6\% pada air limbah asli dan air limbah buatan konsentrasi 30 ppb. Tingkat akumulasi $\mathrm{Hg}$ tertinggi ditemukan di bagian akar tanaman dengan konsentrasi $\mathrm{Hg}$ total pada bagian akar, batang dan daun tanaman Phragmites australis adalah sebesar $3,502 \mathrm{mg} / \mathrm{kg}, 5,102 \mathrm{mg} / \mathrm{kg}$ dan $12,066 \mathrm{mg} / \mathrm{kg}$ pada air limbah buatan konsentrasi 30 ppb, 60 ppb dan 90 ppb. Lebih tingginya tingkat akumulasi $\mathrm{Hg}$ di bagian akar, dibandingkan dengan bagian lain dari tanaman, dapat menjadi suatu tanda bukti bahwa mikroba dari kompos yang menempel pada bagian akar tanaman itu juga ikut berperan dalam proses penyerapan $\mathrm{Hg}$ oleh tanaman.

Kata kunci: lahan basah buatan, merkuri $(\mathrm{Hg})$, tambang emas rakyat, tailing

\section{PENDAHULUAN}

Salah satu dampak kerusakan lingkungan yang dihasilkan dari pertambangan adalah material residu dari proses produksi yang disebut dengan tailing ${ }^{(1,2)}$. Limbah tailing yang merupakan ampas dari sisa pengolahan bahan galian pertambangan memiliki potensi yang cukup besar dalam meningkatkan zat pencemar pada lingkungan. Pada operasi pertambangan emas dan perak berlangsung, sering sekali terdapat beberapa unsur-unsur lain yang hadir dan terlarut dalam eksploitasi pertambangan, unsur tersebut adalah tembaga, timah, seng, nikel, besi dan juga $\mathrm{Hg}^{(3,4,5)}$.

Limbah buangan hasil dari pertambangan tersebut akan menuju badan air terakhir yakni air laut. Bioakumulasi senyawa organik $\mathrm{Hg}$ dalam air limbah tambang emas dapat ikut terbawa hingga ke dalam perairan. Hal ini dapat menyebabkan terakumulasinya senyawa organik $\mathrm{Hg}$ pada tubuh ikan laut, yang dapat memungkinkan $\mathrm{Hg}$ masuk pada rantai makanan, dan dapat menganggu baik lingkungan maupun kesehatan manusia ${ }^{(6)}$. Oleh karena itu pengolahan dalam mengurangi 
konsentrasi $\mathrm{Hg}$ pada badan air menjadi hal dengan prioritas yang cukup tinggi ${ }^{(7)}$.

Oleh karena itu perlu dilakukan suatu pengelolaan agar dapat meminimalisasi potensi pencemaran $\mathrm{Hg}$ pada lingkungan. Metode yang dapat diterapkan salah satunya adalah melalui metode lahan basah buatan (constructed wetland). Lahan basah buatan adalah salah satu cara pengolahan limbah dengan menggunakan prinsip penjernihan air pada lahan basah yang memanfaatkan tanaman pada prosesnya. Sistem penjernihan air di lahan basah ini memiliki prinsip self purification, yaitu tidak ada bahan kimia yang ditambahkan selama proses berlangsung ${ }^{(8)}$. Lahan basah buatan terbukti efektif dalam meningkatkan kualitas air dan mengurangi konsentrasi pencemar di dalamnya ${ }^{(9,10)}$.

Sistem lahan basah buatan (constructed wetlands) dapat terbukti secara efektif dalam menghilangkan padatan yang tersuspensi, polutan organik, dan nutrien dari air limbah ${ }^{(11)}$. Menurut United States Environmental Protection Agency (US EPA), sistem lahan basah buatan ini pun dapat mengurangi kandungan organik dalam limbah hingga $90 \%{ }^{(12)}$. Selain itu, sistem lahan basah buatan ini pun dapat menghemat energi, biaya pembangunan dan operasional yang lebih murah, dan dapat membentuk ekosistem baru, dan memberi nilai estetika pada suatu tempat ${ }^{(13)}$.

Penelitian ini dilakukan dengan tujuan untuk mengetahui efisiensi pengolahan air limbah tailing tambang emas dengan menggunakan remediasi metode lahan basah buatan terpadu antara tanaman dengan mikroba pada daerah akarnya (rizosfer). Penelitian ini melakukan pendekatan kuantitatif dalam rangka menganalisis tingkat efisiensi penurunan konsentrasi $\mathrm{Hg}$ yang dapat dilakukan oleh tanaman Phragmites australis.

Tabel 1. Kebutuhan $\mathrm{HgCl}_{2}$ pada penelitian

\begin{tabular}{c|c}
\hline Konsentrasi Limbah & $\mathbf{H g C l}_{\mathbf{2}}$ \\
\hline $0,03 \mathrm{ppm}$ & $0,001 \mathrm{gram}$ \\
$0,06 \mathrm{ppm}$ & $0,002 \mathrm{gram}$ \\
$0,09 \mathrm{ppm}$ & $0,003 \mathrm{gram}$ \\
\hline
\end{tabular}

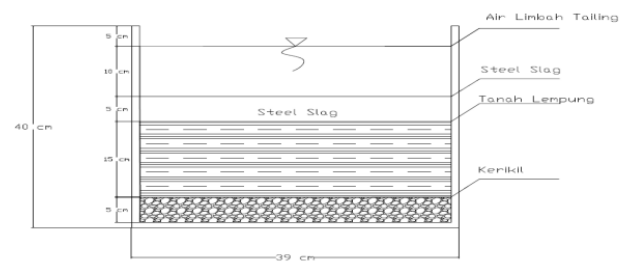

Gambar 1. Disain lahan basah buatan

\section{BAHAN DAN METODE}

Berdasarkan beberapa studi yang dilakukan pada tanaman Phragmites australis, Thypa latifolia dan Scirpus spp, diketahui bahwa ketiga tanaman tersebut berhasil dapat menurunkan konsentrasi $\mathrm{Hg}$ pada air limbah dengan akumulasi penyerapan konsentrasi $\mathrm{Hg}$ terbesar dilakukan oleh tanaman Phragmites australis $^{(14,15)}$. Penelitian lahan basah buatan dengan menggunakan tanaman Pharagmites australis dapat menggunakan pilihan media kerikil sebagai media tanaman dengan ukuran diameter kerikil 5-25 $\mathrm{mm}$ dengan minimal ketinggian media adalah $15 \mathrm{~cm}$, yang dapat digunakan dengan media tanah lempung atau dengan pencampuran pasir dan kerikil. ${ }^{(12)}$

Prosedur penelitian ini terdiri dari beberapa tahap yakni, perancangan lahan basah buatan, pengambilan sampel, pembuatan air limbah buatan dan pengujian karakteristik air limbah. Perancangan lahan basah buatan pada penelitian ini mengacu pada kriteria disain berdasarkan teori yang telah dibahas di berbagai buku tentang lahan basah buatan (constructed wetlands) (Gambar 1) ${ }^{(16,17)}$.

Pengambilan sampel air limbah dilakukan di tambang emas rakyat Kecamatan Nanggung, Pongkor Jawa Barat. Pengambilan sampel air limbah dilakukan pada saluran effluent pembuangan mesin gelundung tambang emas rakyat, dengan melakukan pengujian $\mathrm{pH}$ dan suhu in-situ. Metode pengambilan air limbah dilakukan berdasarkan SNI 6989.59:2008. Pengambilan sampel air limbah yang diangkut pada masing-masing tambang adalah 30 liter.

Pembuatan air limbah buatan dilakukan dengan 3 variasi berdasarkan karakteristik air limbah tailing tambang Pongkor yang telah dilakukan sampling terlebih dahulu. Berdasarkan data yang diperoleh diketahui bahwa konsentrasi $\mathrm{Hg}$ terendah pada air limbah tailing tambang emas rakyat adalah 0,027 ppm dan Hg tertinggi adalah sebesar 0,083 ppm. Berdasarkan data tersebut, maka variasi air limbah buatan ditetapkan sebesar 0,03 ppm, 0,06 ppm dan 0,09 ppm (Tabel 1). Pembuatan air limbah buatan ini dilakukan dengan melakukan pencampuran sebanyak jumlah milligram $\mathrm{Hg}$ yang hendak dituju dengan 1 liter air, dan kemudian di aduk dengan mesin pengaduk. Selanjutnya air limbah buatan sudah dapat langsung digunakan.

\subsection{Proses Penelitian}

Proses penelitian ini dilakukan secara bersamaan terdiri dari 3 proses, yakni penurunan konsentrasi $\mathrm{Hg}$ dengan limbah asli, limbah buatan serta adanya uji positif dan negatif. Penelitian ini diawali dengan melakukan penanaman tanaman pada media tanaman dan reaktor yang disediakan. Selanjutnya adalah mengalirkan air limbah ke dalam reaktor yang telah diberi label. Percobaan dilakukan selama 7 hari, dan dengan waktu detensi yang ditetapkan selama 1 hari maka pada hari di mana air limbah 
dimasukkan dikategorikan menjadi hari ke-0 dan pengecekan $\mathrm{Hg}$ dilakukan pada hari ke-1, 2, 3, 4, 5 dan berlaku kelipatannya.

Penelitian dengan limbah buatan memiliki 3 konsentrasi variasi $\mathrm{Hg}$ di dalamnya yakni 0,03 ppm, 0,06 ppm dan 0,09 ppm (Tabel 1). Selanjutnya ketiga konsentrasi tersebut dimasukkan ke dalam 6 reaktor yang berbedabeda, tetapi dengan perlakuan dan jumlah tanaman yang sama. Ketiga limbah buatan dilakukan dengan running duplo (dua ulangan) secara bersamaan. Terdapat tiga reaktor lainnya yang berisi limbah asli, serta kontrol positif dan kontrol negatif. Reaktor pada kontrol positif dan kontrol negatif akan diisi dengan limbah buatan 0,06 ppm Hg.

Penelitian ini dilakukan dengan menggunakan tanaman Phragmites australis dan media tanamannya adalah tanah merah, kompos dan kerikil. Sedangkan penelitian dengan limbah asli dilakukan dengan limbah asli yang berasal dari tambang emas rakyat yang kemudian dimasukkan ke dalam reaktor dengan tanaman Phragmites australis. Limbah tersebut juga mendapatkan perlakukan yang sama seperti pada perlakuan air limbah buatan.

Pengujian karakteristik air limbah yang digunakan pada penelitian ini adalah pengujian konsentrasi $\mathrm{Hg}$, pH dan suhu. Pengujian seluruh parameter dilakukan setiap hari. Perubahan nilai akumulasi Hg pada Phragmites australis terdapat pada bagian akar, batang dan daun. Oleh karena itu untuk melihat tingkat efisiensi penurunan konsentrasi $\mathrm{Hg}$ yang telah diserap oleh tanaman, maka perlu dilakukan pengukuran nilai akumulasi $\mathrm{Hg}$ pada tanaman Phragmites australis yang dilakukan sebelum dan sesudah tanaman ditanam pada lahan basah buatan.

Pada penelitian ini terdapat limbah sintetis yang dibandingkan dengan perlakuan lahan basah buatan (constructed wetland) antara limbah sintetis dengan limbah asli. Pada pembuatan limbah buatan sintetis digunakan $\mathrm{Hg}$ klorida $\left(\mathrm{HgCl}_{2}\right)$ untuk membentuk konsentrasi larutan yang diinginkan. Perhitungan ini dapat dilakukan dengan cara menggunakan perbandingan massa 1 molekul senyawa $\mathrm{Hg}$ klorida $\mathrm{Mr}$ 271,496 dengan massa atom relatif $\mathrm{Hg}$ di dalam $\mathrm{Hg}$ klorida $\left(\mathrm{HgCl}_{2}\right)$, yakni 200,59. Maka perhitungan untuk mendapatkan konsentrasi 1 ppm Hg pada 30 liter air adalah sebagai berikut :

$$
\text { Massa } \mathrm{HgCl}_{2} \text { untuk kualitas 0,03 ppm }
$$

$$
=\frac{0,03^{m g} d_{L} x 271,496}{200,59} \times 30 \mathrm{~L}=0,001 \mathrm{gr}
$$

\subsection{Analisis Data}

Data yang telah diperoleh lalu dianalisis dan dibuat tabel serta grafiknya untuk mengetahui perbedaan penurunan konsentrasi $\mathrm{Hg}$ dalam masing-masing sistem yang mendapatkan perlakuan berbeda.

\section{HASIL DAN PEMBAHASAN}

\subsection{Kinerja dan Efektivitas Lahan Basah Buatan}

Lahan basah buatan yang digunakan pada penelitian ini memiliki sistem batch dengan tipe aliran free water surface dan menggunakan tanaman rawa Phragmites australis. Lahan basah buatan penelitian diletakkan pada kondisi yang cukup stabil di dalam Rumah Kaca Balai Teknologi Lingkungan BPPT. Gambar 2 adalah lahan basah buatan penelitian skala batch yang sudah dilakukan.

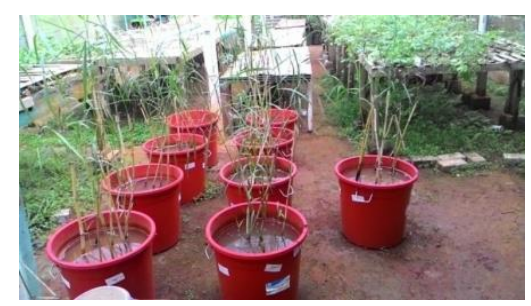

Gambar 2. Lahan basah buatan untuk penelitian

Pada sistem yang menggunakan sistem bacth, material yang masuk ke dalam sistem hanya dilakukan sebanyak 1 kali pada saat awal perlakuan/penelitian. Jika lahan basah buatan penelitian diletakkan di area yang terbuka, peluang kesalahan pada sistem dapat meningkat, seperti adanya penambahan volume air pada reaktor saat kondisi hujan atau adanya penambahan material tidak diinginkan ke dalam reaktor yang berasal dari lingkungan sekitarnya. Untuk meminimalisir hal tersebut, maka lahan basah buatan penelitian diletakkan di dalam area rumah kaca.

Suhu udara, kelembapan udara serta intensitas cahaya yang relatif konstan juga merupakan salah satu keunggulan penanaman yang dilakukan di dalam rumah kaca. Intensitas cahaya matahari yang berlebihan merupakan kondisi lingkungan yang tidak dikehendaki oleh tanaman, dikarenakan adanya ekses radiasi sinar ultra violet dan sinar infra merah, juga karena jenis dan karakteristik Phragmites australis yang senang dengan intensitas cahaya sedang $^{(18)}$. Selain itu, dengan adanya rumah kaca, kondisi suhu udara bagi tanaman dan sistem pada penelitian menjadi lebih stabil, terutama pada tingkat penguapan air limbah yang mengandung $\mathrm{Hg}$ karena logam $\mathrm{Hg}$ tersebut memilki sifat yang tidak stabil ${ }^{(7)}$. Keunggulan lain rumah kaca bagi kinerja dan efektivitas sistem lahan basah buatan penelitian ini adalah dapat melindungi tanaman dari gangguan hama 
penyakit, serta meminimalkan gangguan fisik bagi tumbuhan baik oleh hewan maupun kecepatan angin yang dapat merobohkan tanaman dan mengganggu sistem kerja lahan basah buatan secara keseluruhan.

Lahan basah buatan pada penelitian ini menggunakan sistem batch. Simulasi prediksi limbah $\mathrm{Hg}$ sangat sulit dilakukan, dan estimasi $\mathrm{Hg}$ dapat dilakukan pada percobaan eksperimen dengan menggunakan sistem batch ${ }^{(19)}$. Tipe aliran lahan basah buatan yang digunakan menggunakan tipe free water surface. Hal ini dikarenakan kondisi penelitian dilakukan sesuai dengan kondisi aslinya yakni pada keadaan free water surface.

\subsection{Penurunan Konsentrasi $\mathrm{Hg}$}

Hasil penelitian menunjukkan sistem lahan basah buatan yang digunakan berhasil melakukan penurunan konsentrasi $\mathrm{Hg}$ dengan baik pada air limbah sintetis dan limbah asli. Pada limbah dengan konsentrasi buatan 0,03 ppm, 0,06 ppm dan reaktor kontrol negatif, penghilangan konsentrasi $\mathrm{Hg}$ didapatkan pada hari ke-4 penelitian. Sedangkan pada konsentrasi buatan 0,09 ppm dan reaktor kontrol positif penghilangan total $\mathrm{Hg}$ didapatkan pada hari ke-5. Pada sistem dengan limbah asli, penghilangan konsentrasi $\mathrm{Hg}$ didapatkan pada hari penelitian ke-3. Tabel 3 menunjukkan tingkat efisiensi akumulatif $\mathrm{Hg}$ pada sistem lahan basah buatan yang sudah dilakukan.

Tabel 2. Konsentrasi $\mathrm{Hg}$ yang dipakai dalam penelitian

\begin{tabular}{crrrrrr}
\hline Hari ke- & $\mathbf{0 , 0 3} \mathbf{~ p p m}$ & $\mathbf{0 , 0 6} \mathbf{~ p p m}$ & $\mathbf{0 . 0 9} \mathbf{~ p p m}$ & Kontrol Positif & Kontrol Negatif & Limbah Asli \\
\hline 0 & $84 \%$ & $93 \%$ & $72 \%$ & $46 \%$ & $94 \%$ & $84 \%$ \\
1 & $88 \%$ & $97 \%$ & $84 \%$ & $47 \%$ & $97 \%$ & $91 \%$ \\
2 & $98 \%$ & $98 \%$ & $91 \%$ & $77 \%$ & $98 \%$ & $100 \%$ \\
3 & $100 \%$ & $100 \%$ & $96 \%$ & $98 \%$ & $100 \%$ & $100 \%$ \\
4 & $100 \%$ & $100 \%$ & $100 \%$ & $100 \%$ & $100 \%$ & $100 \%$ \\
5 & $100 \%$ & $100 \%$ & $100 \%$ & $100 \%$ & $100 \%$ & $100 \%$ \\
\hline
\end{tabular}

Tabel 3. Tingkat Efisiensi Konsentrasi $\mathrm{Hg}$

\begin{tabular}{crrrrrr}
\hline Hari ke- & $\mathbf{0 , 0 3}$ ppm & $\mathbf{0 , 0 6}$ ppm & $\mathbf{0 . 0 9}$ ppm & Kontrol Positif & Kontrol Negatif & Limbah Asli \\
\hline 0 & $84 \%$ & $93 \%$ & $72 \%$ & $46 \%$ & $94 \%$ & $84 \%$ \\
1 & $88 \%$ & $97 \%$ & $84 \%$ & $47 \%$ & $97 \%$ & $91 \%$ \\
2 & $98 \%$ & $98 \%$ & $91 \%$ & $77 \%$ & $98 \%$ & $100 \%$ \\
3 & $100 \%$ & $100 \%$ & $96 \%$ & $98 \%$ & $100 \%$ & $100 \%$ \\
4 & $100 \%$ & $100 \%$ & $100 \%$ & $100 \%$ & $100 \%$ & $100 \%$ \\
5 & $100 \%$ & $100 \%$ & $100 \%$ & $100 \%$ & $100 \%$ & $100 \%$ \\
\hline
\end{tabular}

Proses pengangkutan $\mathrm{Hg}$ pada umumnya memakan waktu yang relatif singkat ${ }^{(7)}$. Terlihat dari penghilangan konsentrasi $\mathrm{Hg}$ pada beberapa variasi konsentrasi air limbah dalam rentang 3-5 hari. Terdapat beberapa faktor yang dapat mempengaruhi proses penghilangan konsentrasi $\mathrm{Hg}$ pada air limbah, yakni (1) proses penyerapan logam berat pada tanaman, (2) proses penguapan dan (3) proses pembentukan senyawa kimia baru oleh metal pada tanah. Penyisihan $\mathrm{Hg}$ yang dilakukan pada penelitian ini dapat dikatakan berhasil sesuai acuan dengan Baku Mutu Lingkungan Keputusan Menteri Lingkungan Hidup Nomor 202 Tahun 2004 Tentang Baku Mutu Air Limbah Bagi Usaha dan Atau Kegiatan Pertambangan Bijih Emas dan atau Tembaga.

\subsection{Parameter Kontrol: pH}

Nilai $\mathrm{pH}$ merupakan salah satu parameter kontrol yang ditinjau pada penelitian ini. Nilai $\mathrm{pH}$ atau derajat keasaman memainkan peranan penting dalam pertumbuhan mikroorganisme dan proses fotosintesis tanaman ${ }^{(19)}$. Berdasarkan Gambar 3 dapat terlihat adanya perubahan $\mathrm{pH}$ pada air limbah selama penelitian berlangsung. Pada hari ke-0 masing-masing air limbah memiliki pH diatas 6,8. Namun setelah hari ke-1 nilai $\mathrm{pH}$ air limbah terus menurun menjadi lebih asam hingga puncak penurunan terjadi pada hari ke-3 penelitian. Pada hari ke-4 secara umum seluruh $\mathrm{pH}$ pada air limbah cenderung naik diikuti hingga hari ke-5 penelitian. Derajat keasaman atau $\mathrm{pH}$ dapat menggambarkan tingkat kontaminan pada air limbah tersebut. 


\subsection{Akumulasi Hg pada Tanah}

Perhitungan akumulasi $\mathrm{Hg}$ pada tanah menjadi sebuah hal yang penting untuk dianalisa dalam melakukan perhitungan penurunan konsentrasi $\mathrm{Hg}$ pada sistem lahan basah buatan. Ketika air limbah dialirkan pada sistem lahan basah buatan (constructed wetland) maka air tersebut akan langsung memiliki kontak dengan media lahan basah buatan (constructed wetland). Komposisi mineral pada media lahan basah buatan (constructed wetland) akan memiliki pengaruh dalam dinamika proses penyerapan $\mathrm{Hg}$ di dalam lahan basah buatan ${ }^{(7)}$ dan akan mempengaruhi tingkat akumulasi adsopsi $\mathrm{Hg}$ dalam $\operatorname{tanah}^{(20)}$. Walaupun lahan basah buatan yang digunakan pada penelitian ini memperhitungkan ketersediaan bahan dan material, namun melakukan selektifiktas pada material menjadi penting dalam rangka upaya maksimal untuk menurunkan konsentrasi kontaminan dalam air.

Berdasarkan penelitian yang dilakukan oleh El-Agroudy ${ }^{(7)}$, terdapat 4 hal yang dapat mempengaruhi total akumulasi penyerapan $\mathrm{Hg}$ pada permukaan tanah sistem lahan basah buatan (constructed wetland), yaitu (1) konsentrasi limbah $\mathrm{Hg}$ yang diberikan, (2) luasan area permukaan tanah, (3) pH larutan dan (4) Konsentrasi padatan dalam (mg/L). Pada penelitian ini penyerapan total akumulasi total $\mathrm{Hg}$ dalam tanah hanya akan ditinjau melalui variasi konsentrasi limbah $\mathrm{Hg}$ yang diberikan, hal ini dikarenakan tujuan dari penelitian adalah melihat penurunan konsentrasi $\mathrm{Hg}$ pada variasi konsentrasi limbah yang diberikan pada sistem lahan basah buatan (constructed wetland). Sedangkan pada penelitian tidak diberlakukan adanya perbedaan luasan area permukaan tanah pada sistem, dikarenakan seluruh sistem lahan basah buatan menggunakan ukuran dan jenis reaktor yang sama, serta tidak adanya variasi $\mathrm{pH}$ larutan dan konsentrasi padatan yang berbeda sebab seluruh larutan dan padatan dalam sistem lahan basah buatan (constructed wetland) berada dan diproses dalam kondisi yang sama. Data pada Tabel 4 adalah hasil penelitian total akumulasi $\mathrm{Hg}$ pada tanah akibat variasi konsentrasi limbah $\mathrm{Hg}$ di dalam air.

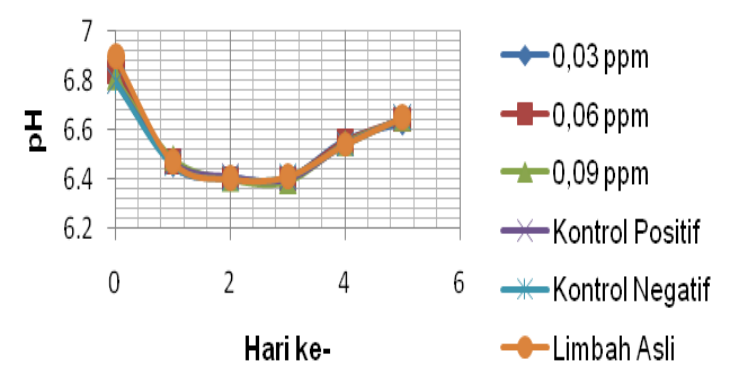

Gambar 3. Grafik Perbandingan pH dan waktu

Tabel 4. Total Akumulasi Hg Pada Tanah

\begin{tabular}{lcr}
\hline Nama & Satuan & Jumlah \\
\hline Limbah Sintetis 0,03 ppm & ppm & 0.021 \\
Limbah Sintetis 0,06 ppm & ppm & 0.027 \\
Limbah Sintetis 0,09 ppm & ppm & 0.082 \\
Kontrol Positif $(0,06 \mathrm{ppm})$ & $\mathrm{ppm}$ & 0.030 \\
Kontrol Negatif $(0,06 \mathrm{ppm})$ & $\mathrm{ppm}$ & 0.030 \\
Limbah Asli $(0,027 \mathrm{ppm})$ & $\mathrm{ppm}$ & 0.016 \\
\hline
\end{tabular}

Tabel 5. Perbandingan akumulasi Hg pada air dan tanah

\begin{tabular}{lcccc}
\hline \multicolumn{1}{c}{ Nama } & Satuan & Tanah & Air & Persentase (\%) \\
\hline Limbah Sintetis 0,03 ppm & ppm & 0.021 & 0.033 & $64 \%$ \\
Limbah Sintetis 0,06 ppm & ppm & 0.027 & 0.063 & $43 \%$ \\
Limbah Sintetis 0,09 ppm & ppm & 0.082 & 0.087 & $94 \%$ \\
Kontrol Positif (0,06 ppm) & ppm & 0.030 & 0.061 & $48 \%$ \\
Kontrol Negatif (0,06 ppm) & ppm & 0.030 & 0.064 & $47 \%$ \\
\hline
\end{tabular}




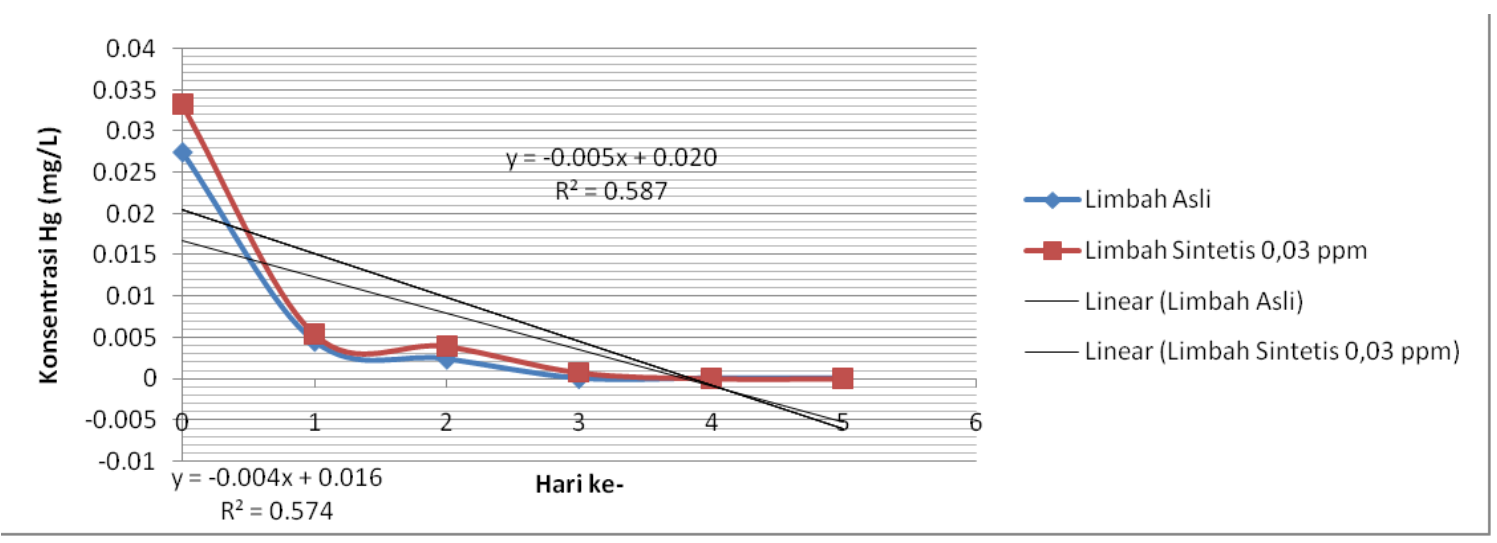

Gambar 4. Grafik perbandingan penurunan konsentrasi $\mathrm{Hg}$ limbah asli dan limbah sintetis

Tabel 6. Data akumulasi $\mathrm{Hg}(\mathrm{Hg})$ pada tanaman

\begin{tabular}{lcccccc}
\hline Perlakuan & Satuan & \multicolumn{2}{c}{ Konsentrasi Hg (ppm) } & $\begin{array}{c}\text { Rasio } \\
\text { Konsentrasi } \\
\text { Akar/Tajuk }\end{array}$ & $\begin{array}{c}\text { Total Hg pada } \\
\text { tanaman (ppm) }\end{array}$ \\
\hline & & Akar & Batang & Daun & & \\
\hline $0,03 \mathrm{ppm}$ & $\mathrm{ppm}$ & 1,57 & 1,54 & 0,39 & 0,82 & 3,50 \\
$0,06 \mathrm{ppm}$ & $\mathrm{ppm}$ & 3,65 & 1,01 & 0,46 & 2,48 & 5,12 \\
$0,09 \mathrm{ppm}$ & $\mathrm{ppm}$ & 8,76 & 2,77 & 0,53 & 2,65 & 12,07 \\
Kontrol Positif & $\mathrm{ppm}$ & 3,94 & 4,32 & 1,48 & 1,54 & 9,75 \\
Limbah Asli & $\mathrm{ppm}$ & 3,86 & 0,35 & 0,30 & 5,88 & 4,51 \\
\hline
\end{tabular}

Berdasarkan data pada Tabel 4 dapat terlihat bahwa pada limbah konsentrasi $\mathrm{Hg}$ buatan dengan konsentrasi $0,03 \mathrm{pppm}$, total akumulasi $\mathrm{Hg}$ pada media lahan basah buatan (constructed wetland) adalah sebesar $0,021 \mathrm{ppm}$, sedangkan untuk limbah dengan konsentrasi $\mathrm{Hg}$ buatan 0,06 ppm, total akumulasi $\mathrm{Hg}$ pada tanah adalah sebesar 0,027 ppm dan pada limbah buatan dengan konsentrasi $\mathrm{Hg} 0,09 \mathrm{ppm}$ total akumulasi $\mathrm{Hg}$ pada tanah adalah $0,082 \mathrm{ppm}$. Pada limbah asli dengan konsentrasi $0,027 \mathrm{ppm}$ diketahui total akumulasi $\mathrm{Hg}$ pada tanah adalah sebesar 0,016 ppm. Berdasarkan data pada Tabel 4 tersebut juga dapat terlihat adanya penyerapan konsentrasi $\mathrm{Hg}$ yang berasal dari air limbah yang cukup tinggi di dalam tanah.

Data ini menunjukkan bahwa semakin tinggi konsentrasi $\mathrm{Hg}$ pada air limbah yang diberikan pada suatu sistem lahan basah buatan (constructed wetland), maka jumlah akumulasi penyerapan $\mathrm{Hg}$ pada permukaan tanah akan semakin meningkat. Hal ini sejalan dengan penelitian yang telah dilakukan oleh El-Agroudy pada tahun $1999^{(7)}$, dimana seiring besarnya konsentrasi limbah $\mathrm{Hg}$ yang diberikan, maka total akumulasi penyerapan $\mathrm{Hg}$ pada tanah pun akan meningkat.

Berdasarkan Tabel 5 diketahui penyisihan $\mathrm{Hg}$ yang terdapat pada permukaan tanah jika dibandingkan dengan karakteristik awal pada air limbah buatan 0,03 ppm Hg mencapai 64\%. Hal ini pun diikuti dengan air limbah buatan konsentrasi 0,06 ppm $\mathrm{Hg}$ dan 0,09 ppm $\mathrm{Hg}$ yakni $43 \%$ dan $94 \%$. Pada limbah buatan dengan konsentrasi $0,06 \mathrm{ppm}$ kontrol positif dan kontrol negatif masing-masing mengalami penyisihan $\mathrm{Hg}$ dari konsentrasi awal adalah sebesar $48 \%$ dan $47 \%$. Tingginya persentase akumulasi $\mathrm{Hg}$ pada tanah hal ini dikarenakan terjadinya reaksi antara $\mathrm{HgCl}_{2}$ dengan $\mathrm{H}_{2} \mathrm{O}$ yang dapat terlihat pada reaksi persamaan berikut :

$$
\mathrm{HgCl}_{2}+\mathrm{H}_{2} \mathrm{O} \rightarrow \mathrm{Hg}(\mathrm{OH}) \mathrm{Cl}+\mathrm{H}^{+}{ }_{(\mathrm{aq})}+\mathrm{Cl}_{(\mathrm{aq})}^{-}
$$

Senyawa $\mathrm{Hg}(\mathrm{OH}) \mathrm{Cl}$ merupakan produk yang dihasilkan dari pencampuran reaksi antara $\mathrm{HgCl}_{2}$ dengan $\mathrm{H}_{2} \mathrm{O}$. Senyawa $\mathrm{Hg}(\mathrm{OH}) \mathrm{Cl}$ tersebut memiliki massa molar 253,05 gram/mol. Jika 
dibandingkan dengan massa molar $\mathrm{Hg}^{0}$ adalah 200,59 gram/mol maka $\mathrm{Hg}(\mathrm{OH}) \mathrm{Cl}$ memiliki massa yang lebih berat dibandingkan massa $\mathrm{Hg}^{\circ}$. Melalui gaya gravitasi yang terjadi, maka $\mathrm{Hg}(\mathrm{OH}) \mathrm{Cl}$ tersebut dapat dengan mudah jatuh pada media lahan basah buatan (constructed wetland) dan terakumulasi pada tanah.

Pada limbah asli diketahui perbandingan total akumulasi $\mathrm{Hg}$ di tanah adalah $59,62 \%$ dari konsentrasi $\mathrm{Hg}$ awal yang terdapat pada air limbah. Karakteristik $\mathrm{Hg}$ yang dihasilkan oleh air limbah tailing pertambangan emas rakyat adalah $\mathrm{Hg}^{0}$ dengan massa molar adalah sebesar 200,59 gram $/ \mathrm{mol}$.

Jika molar massa $\mathrm{Hg}(\mathrm{OH}) \mathrm{Cl}$ dan $\mathrm{Hg}^{0}$ dibandingkan pula dengan molar massa $\mathrm{H}_{2} \mathrm{O}$ (air) sebesar 18,02 gram $/ \mathrm{mol}$ maka adanya penurunan senyawa $\mathrm{Hg}(\mathrm{OH}) \mathrm{Cl}$ dan $\mathrm{Hg}^{0}$ dengan gaya gravitasi dapat mungkin terjadi, hingga total akumulasi $\mathrm{Hg}$ di tanah menjadi lebih dominan dan tinggi dibandingkan di air.

Hal yang sama terjadi pula pada keadaan asli di lokasi tambang emas rakyat di Pongkor, Jawa Barat. Berdasarkan penelitian yang dilakukan oleh sebelumnya diketahui bahwa konsentrasi konsentrasi $\mathrm{Hg}(\mathrm{Hg})$ air limbah tailing memiliki kisaran antara 0,004 - 0,39 ppm sedangkan pada sedimen tailing diketahui konsentrasi konsentrasi $\mathrm{Hg}$ memiliki rentang 22,67 - $598 \mathrm{ppm}^{(21)}$. Hal tersebut dapat memperlihatkan bahwa $\mathrm{Hg}$ dengan karakteristik logam berat dapat sangat mudah terakumulasi dalam padatan berupa lumpur dan tanah dikarenakan massa molar unsur yang besar.

\subsection{Akumulasi Hg pada Tanaman Phragmites australis}

Tanaman air dilaporkan dapat digunakan sebagai katalis alami dalam menyerap dan mengakumulasi logam berat dari air limbah yang terkontaminasi. Tanaman Phragmites australis merupakan tanaman yang paling sering digunakan dalam membantu melakukan pengolahan air limbah pada lahan basah buatan $^{(22)}$. Data hasil penelitian pada Tabel 6 menunjukkan bahwa tingkat akumulasi $\mathrm{Hg}$ pada akar tanaman memiliki konsentrasi yang lebih tinggi dibandingkan dengan konsentrasi $\mathrm{Hg}$ pada batang dan daun di dalam tanaman. Telah banyak sumber dan literatur yang mengemukakan tentang tingkat penyerapan dan akumulasi logam berat pada tanaman air. Hasil yang ditunjukkan pada tanaman air Phragmites australis menunjukkan tingginya konsentrasi konsentrasi logam pada akar, dengan rendahnya konsentrasi konsentrasi logam pada bagian tajuk tanaman ${ }^{(23)}$. Hal ini sesuai dengan penelitian yang dilakukan oleh Bonanno dan Giudice ${ }^{(24)}$ yang menunjukkan bahwa organ tumbuhan bagian bawah merupakan area utama dalam akumulasi penyerapan logam $\mathrm{Cd}, \mathrm{Cr}, \mathrm{Cu}, \mathrm{Hg}$, $\mathrm{Mn}, \mathrm{Ni}, \mathrm{Pb}$ dan $\mathrm{Zn}$. Namun tingkat absorpsi organik dan inorganik logam berat $\mathrm{Hg}$ oleh tanaman dari tanah lebih rendah dibandingkan dengan tingkat absorpsi logam berat lain ${ }^{(25)}$. Hal ini bisa dikarenakan adanya barier saat perpindahan translokasi $\mathrm{Hg}$ dari akar tanaman menuju batang dan daun ${ }^{(15)}$. Pada umumnya logam akan diserap melalui akar lalu naik menuju tajuk tanaman ${ }^{(16)}$, namun berdasarkan penelitian oleh Baldanatoni dan teman-temannya, terdapat beberapa variasi kasus terkait absorpsi dan akumulasi logam berat pada akar dan tajuk tanaman ${ }^{(26)}$.

Berdasarkan data Tabel 6 yang telah dipaparkan, dapat terlihat pula pada air limbah dengan $0,03 \mathrm{ppm} \mathrm{Hg}$ total $\mathrm{Hg}$ yang diserap dan terakumulasi pada tanaman adalah sebesar 3,50 ppm, sedangkan pada konsentrasi air limbah $0,06 \mathrm{ppm}$ total $\mathrm{Hg}$ yang diserap dan terakumulasi pada tanaman adalah sebesar 5,12 ppm dan pada konsentrasi $0,09 \mathrm{ppm} \mathrm{Hg}$ adalah 18,05 ppm. Hal ini memperlihatakan bahwa konsentrasi penyisihan $\mathrm{Hg}$ bergantung pada tingkat kontaminasi $\mathrm{Hg}$ tersebut ${ }^{(27)}$. Semakin tinggi konsentrasi $\mathrm{Hg}$ yang terdapat dalam air, maka semakin tinggi jumlah $\mathrm{Hg}$ yang dapat diserap oleh tanaman ${ }^{(27,28)}$. Faktor genetik dan jenis tumbuhan dapat menjadi salah satu faktor dalam menentukan penyerapan logam pada zona perakaran dan akar/tajuk pada tingkat yang bervariasi $^{(28,29)}$.

Lebih tingginya tingkat reduksi $\mathrm{Hg}$ di bagian perakaran tanaman kemungkinan juga bisa disebabkan karena kinerja mikroba yang terkandung di media tanah dan kompos dalam sistem Lahan Basah Terpadu yang dipakai dalam penelitian ini. Diketahui dari berbagai hasil penelitian sebelumnya, ternyata bakteria rizosfer yang berada di perakaran tanaman mempunyai sifat mampu mereduksi $\mathrm{Hg}$ pula, selain logamlogam berat lainnya ${ }^{(29)}$. Beberapa jenis mikroba yang mampu mendegradasi $\mathrm{Hg}$ diketahui mempunyai enzim $\mathrm{Hg}$ reduktase, misalnya Pseudomonas putida, Geobacter metallireducens, Shewanella putrefaciens, Desulfovibrio desulfuricans, dan D. vulgaris ${ }^{(30)}$. Beberapa genus Rhizobium juga diketahui mempunyai peranan dalam proses bioremediasi logam pada lahan-lahan tercemar karena mereka mempunyai enzim metalothionin ${ }^{(31,32)}$.

\section{KESIMPULAN}

Berdasarkan hasil kajian pustaka dan penelitian yang telah dilakukan maka dapat disimpulkan bahwa konsentrasi $\mathrm{Hg}$ pada air limbah tailing tambang emas rakyat di Pongkor Jawa Barat adalah berkisar antara 0,027 ppm (27 $\mathrm{ppb})-0,082 \mathrm{ppm}(82 \mathrm{ppb})$. Penurunan derajat 
keasaman $(\mathrm{pH})$ berbanding lurus dengan penurunan konsentrasi $\mathrm{Hg}(\mathrm{Hg})$ pada air limbah Massa molar senyawa $\mathrm{Hg}(\mathrm{OH}) \mathrm{Cl}$ sebesar 253,05 gram/mol dan massa molar $\mathrm{Hg}^{0}$ sebesar 200,59 $\mathrm{gram} / \mathrm{mol}$ yang lebih besar dibandingkan dengan massa molar $\mathrm{H}_{2} \mathrm{O} \quad 18,02 \mathrm{gram} / \mathrm{mol}$ menyebabkan senyawa $\mathrm{Hg}(\mathrm{OH}) \mathrm{Cl}$ dan $\mathrm{Hg}^{0}$ mudah terendapkan ke sedimen tanah atau lumpur dengan gaya gravitasi. Semakin besar kontak luas area antara permukaan tanah dengan air limbah, maka penghilangan konsentrasi $\mathrm{Hg}$ dalam air limbah akan semakin cepat

Dari hasil penelitian terbukti bahwa sistem lahan basah buatan dengan tanaman Phragmites australis terbukti dapat menyerap $\mathrm{Hg}$ pada air limbah $\mathrm{Hg}$ dengan tingkat efisiensi mencapai $99,8 \%$ pada air limbah buatan konsentrasi 0,06 ppm dan 0,09 ppm. Serta pada limbah asli dan limbah buatan konsentrasi $0,03 \mathrm{ppm}$ dengan tingkat efisiensi mencapai 99,6\%. Tingkat akumulasi $\mathrm{Hg}$ pada tanaman Phragmites australis lebih tinggi ditemukan di bagian akar dibandingkan dengan bagian batang dan daun dengan konsentrasi $\mathrm{Hg}$ ditemukan di akar berturut-turut adalah sebesar 1,57 ppm, 3,65 ppm dan 8,76 ppm pada air limbah buatan $\mathrm{Hg}$ dengan konsentrasi $0,03 \mathrm{ppm}, 0,06 \mathrm{ppm}$ dan $0,09 \mathrm{ppm}$. Hal ini disebabkan karena adanya populasi mikroba pada bagian perakaran yang bersentuhan langsung dengan media tanah dan kompos yang dipakai dalam sistem lahan basah pada penelitian ini, sehingga mikroba tersebut ikut berperan membantu tanaman dalam mereduksi $\mathrm{Hg}$ di bagian perakarannya. Semakin tinggi konsentrasi $\mathrm{Hg}$ pada air limbah maka semakin tinggi tingkat akumulasi $\mathrm{Hg}$ pada tanaman Phragmites australis. Total $\mathrm{Hg}$ pada tanaman berturut-turut adalah sebesar 3,50 ppm, 5,12 ppm dan 12,07 ppm pada air limbah buatan $\mathrm{Hg}$ dengan konsentrasi 0,03 ppm, 0,06 ppm dan $0,09 \mathrm{ppm}$.

\section{PERSANTUNAN}

Ucapan terima kasih yang sebesar-besarnya ditujukan kepada pimpinan BPPT, khususnya Kepala Balai Teknologi Pengolahan Air dan Limbah (BTPAL)-TPSA, yang telah memberikan izin untuk menggunakan fasilitas laboratorium mikrobiologi dan laboratorium proses selama penelitian ini dilakukan. Terima kasih juga diucapkan kepada semua rekan kerja, terutama yang terlibat dalam laboratorium mikrobiologi, laboratorium fitoteknologi dan laboratorium analitik, atas segala bantuan dan kerjasamanya selama penelitian ini.

\section{DAFTAR PUSTAKA}

1. Halimah, (2003), Pencemaran $\mathrm{Hg}$ dan Strategi Penanganan Penambangan Emas Tanpa Izin (PETI) di Pongkor, Jawa Barat. Skripsi S1, Universitas Indonesia.

2. Lottermoser-Marchand, M.M. (2010), Metal And Metalloid Removal In Constructed Wetlands, With Emphasis On The Importance Of Plants And Standardized Measurements: A Review, Environmental Pollution, 3447-3461.

3. Diaz, E., (2000), Mercury Pollution at Gold Mining Sites in the Amazon Environment, Doctoral Thesis, University of Idaho.

4. Corral, M.D., (2009), Gold Mining: Formation and Resource Estimation. Economics and Environmental Impact, New York, Nova Science Publishers, Inc.

5. Odumo, B.O., Carbonell, G., Angeyo, H.K., Patel, J.P., (2014), Impact Of Gold Mining Associated With Mercury Contamination In Soil, Biota Sediments And Tailing In Kenya, New York, Springer Publisher.

6. WHO, (2013), Mercury and Health. Available from WHO: http://www.who.int/, (viewed on June 13, 2015).

7. El-Agroudy, A.A., (1999). Investigation of Constructed Wetlands Capability to Remove Mercury from Contaminated Waters. Montreal, Canada.

8. Hammer, M.J., (1986). Waste Water Technology, $3^{\text {rd }}$ Edition, New York, Prentice Hall International.

9. Antoinette, M., (2014). Penyisihan Konsentrasi Krom Hexavalen pada Air Limpasan Hujan Pertambangan Nikel dengan Metode Lahan Basah Buatan (Constructed Wetlands) Menggunakan Thypa latifolia, Skripsi S1, Universitas Indonesia.

10. Zahra, F.A., (2015), Pengolahan Air Limbah Domestik (Grey Water) Komunal dengan Lahan Basah Buatan Sistem Aliran Bawah Permukaan dengan Kombinasi Tanaman Canna indica dan Pontederia Sp. serta Media Serbuk Arang, Skripsi S1, Universitas Indonesia.

11. Vyamazal, J., (2008), Constructed Wetlands For Wastewater Treatment: A Review, Proceeding of Taal 2007: The $12^{\text {th }}$ World Lake Conference, 958-980.

12. USEPA, (1999), Manual Constructed Wetlands Treatment of Municipal Wastewaters, Ohio: USEPA. 
13. Kent, (2001), Applied Wetlands Science and Technology, Boca Raton: CRC Press.

14. Kamal, M., Ghaly, A., Mahmoud, N., Cote, R., (2004) Phytoaccumulation Of Heavy Metals By Aquatic Plants, Environment International, 1029-1039.

15. Afrous, A., Mashouri, M., Liaghat, A., Pazira, E., Sedghi, H., (2011), Mercury And Arsenic Accumulation By Three Species Of Aquatic Plants In Dezful, Iran, African Journal of Agricultural Research, 5391-5397.

16. Kandasamy, J.V., (2009), Constructed Wetlands, New York: Nova Science Publisher, Inc.

17. Katima, J.H.Y.L.G., (2013), Treatment Of Acid Mine Drainage Using Constructed Wetlands In Tropical Environment: A Tanzania Case Report. Journal of Agricultural Science and Technology, 439446.

18. Hickman, J., (1993), The Jepson Manual: Higher Plants of California, Barkeley, CA: University of California Press.

19. Essington, M.E., (2015), Soil and Water Chemistry, Boca Raton: CRC Press.

20. Yong, A.M., (1992), Principles of Contaminant Transport in Soils, New York: Elsevier.

21. Juhaeti, N.H., (2009), Tumbuhan Akumulator Untuk Fitoremediasi Lingkungan Tercemar Hg dan Sianida Penambangan Emas, Bogor: LIPI Press.

22. Vyamazal, J., Kropfelova, L., (2008), Wastewater Treatment In Constructed Wetlands With Horizontal Sub-Surface Flow, Dordrecht, The Netherlands.

23. Windham, L., Weis, J., Weis, P., (2003), Uptake And Distribution Of Metals In Two Dominant Salt Marsh Macrophytes, Spartine Alternifola (Cordgrass) And Phragmites Australis (Common Reed), Estuarine, Coastland, And Shelf Sciences, 63-72.
24. Bonanno, G., Giudice, R., (2010), Heavy Metal Bioaccumulation By The Organs Of Phragmatis australis (Common Reed) And Their Potential Use As Contamination Indicators, Ecological Indicators, 639-645.

25. Lodenius, M., (1980), Environmental Mobilization of Mercury and Cadmium, Helsinki: Department of Environmental Conversation, University of Helsinki.

26. Baldanatoni, D., Alfani, A., Tommasi, P.D., Bartoli, G., Santo, A.V., (2004), Assessment Of Macro And Microelement Accumulation Capability Of Two Aquatic Plants, Environmental Pollution, 149-156.

27. Skinner, K., Wright, N., Porter-Goff, E., (2007), Mercury Uptake And Accumulation By Four Species Aquatic Plants, Environmental Pollution, 234-237.

28. Rahmansyah, M., Hidayati, N., Juhaeti, T., (2009), Tumbuhan Akumulator untuk Fitoremediasi Lingkungan Tercemar $\mathrm{Hg}$ dan Sianida Penambangan Emas, Bogor: LIPI Press.

29. Hidayati, N., Juhaeti, T., Syarif, F., (2009), Mercury and Cyanide Contamination in Gold Mine Environment and Possible Solution of Cleaning Up by Using Phytoextraction, Bogor: LIPI Press, 88-94.

30. Prasetyawati, E.T., (2009), Bakteri Rhizosfer Sebagai Pereduksi Hg dan Agensia Hayati, UPN Press ISBN 978-979-3100-95-1.

31. Widyati, E., (2008), Peranan Mikroba Tanah Pada Kegiatan Rehabilitasi Lahan Bekas Tambang (Roles Of Soil Microbes In ExMining Land Rehabilitation), Info HUTAN Vol. 5 (2), 151-160.

32. Khan, A.G., Kuek, C., Chaudry, T.M., Khoo, C.S., Hayes, W.J., (2000), Role Of Plants, Mycorrhizae And Phytochelators In Heavy Metal Contaminated Land Remediation, Chemosphere 21, 197-207. 